\title{
Some Reflections on the Genefics of Mental Disorder
}

\author{
by \\ INGRAM F. ANDERSON. M.B.B.Ch.(Rand.) \\ Department of Medicine and Clinical Genetics Unit, Johannesburg General Hospital.
}

\begin{abstract}
"Heredity, the only one of the Gods whose real name we know ... brings gifts of strange temperaments ... and impossible desires." -
\end{abstract}

\section{Oscar Wilde.}

A study of aberrant mental mechanisms involves consideration of the interaction of the soma, psyche and multiform environment. Such a vast field cannot be surveyed critically or even adequately in a dissertation of this nature. The title of the paper is thus employed advisedly: "some" because the scope is necessarily limited, "reflections" because here are mirrored my thoughts and those of others which may not be true images, "genetics" indicates etiologic restriction and "mental disorder" is used in the broad sense.

The average medical-man, like the man in the street, has very little occasion to come up against cases of mental abnormality. The latter are locked away early - out of harm's way, out of society's way, out of medicine's way . . . However most of the major advances in genetics and especially in cytogenetics in the last few years have evolved against this very background and notably within its parameters, as exemplified in the case of mongolian idiocy. The recent splurge of spiders across the erstwhile neatly-lined pages of the medical journals has seemed to many to represent the soap-bubble interest of a narrow speciality. On the contrary, the implications have been widespread and diverse, and have impinged upon the whole broad structure of medical-biology.

It is noteworthy that the layman has always been aware of an hereditary component in mental illness, as evidenced by everyday statements such as, "There's madness in X's family. Comes through the father's side it does!" The medical world has been tardy in accepting such a situation and only in the last few decades has it given concrete formulation to the concept. The current explosion of activity and interest in human genetics has again focussed attention on the domain of the psychiatrist.
Whereas psychiatric genetics previously appeared to be an empiric exercise and its applications in mental disease were thought to denote a state of irreversibility, it now provides a point of vantage for research and therapeutic application. Thus a genetically determined biochemical disturbance may not only point the way to new means of diagnosis but offers possibilities of correction at the molecular level.

With these introductory remarks it will be propitious to pass on to a consideration of (A) Mental Deficiency and (B) The Psychoses.

\section{(A) MENTAL DEFICIENCY.}

About one out of every thousand whites in this country is in a mental asylum because of mental deficiency. The problem comprises elements of considerable philosophic and social importance; it provokes the question of why people are different and what determines their individuality; it limelights the paradox of human rights and raises the polemic aspects of eugenics as these reflect in the mirror of human ecology.

Almost half of the institutionalised cases are simple oligophrenics. So-called simple mental deficiency involves the genetics of intelligence. The latter is a tenuous entity, dependent on multifactorial inheritance and it is safe to say that its precise nature remains a matter of controversy. One reads in the book of Job:

\footnotetext{
"But where shall Wisdom be found? And where is the place of understanding? Man knoweth not the price thereof; Neither is it found in the land of the living. The deep sayeth it is not in me And the sea sayeth it is not with me. It cannot be gotten for gold,

Neither shall silver be weighed for the price thereof.

Whence then cometh Wisdom?

And where is the place of understanding?..."
}

For our purposes, we note that the simple moron has no distinctive characters and statisically lies at the negative end of the 
Gaussian distribution of intelligence. In contrast to this somewhat ubiquitous entity, great strides have been made in our understanding of two definitive types of mental defect, namely, mongolism and phenylketonuric oligophrenia.

\section{(1) Mongolism.}

It is convenient to discuss this in terms of a collocation of the three time factors in the biologic picture. On the largest scale is Evolution, with Man the result of a long line of ancestors and himself the potential ancestor of a long line of descendants. The interest here is historic. When Langdon-Down published his classic paper on "An Ethnic Classification of Idiots". in 1866, he described Mongolism for the first time, characterising the mongol as, ". . . a representative of the great Mongolian race". Crookshank in 1931 added the hypothesis that these cases were derived from Mongolian ancestors and further that they represented an atavistic return towards the orang-utang. There is no scientific validity for this idea and the anomaly can be readily recognised in the Mongol race itself. Because of this confused inference attendant on the name, the designation Langdon-Down Syndrome has been preferred by many.

On the intermediate time-scale we consider the individual as such - his life history. Mongolism exceeds all other morbid conditions of severe mental retardation in number, constituting some 5 to $10 \%$ of asylum inmates. There are approximately 125 mongols at the institution at Witrand. The incidence in the population is nearly one in every 600 births. As a comparative measure it is salutory to note that the incidence of hypertensive disease is $5 \%$, of all forms of congenital heart disease about $1 \%$, while myelomatosis accounts for 3 per 100,000 of the population.

The child with mongolism is usually born into a normal family with parents and siblings often above average intelligence. An enormous psycho-social problem is at once generated and cannot be elaborated upon here. Apart from the mental subnormality, mongols exhibit extensive physical abnormality, proneness to infection being quite a feature. The advent of the antibiotic era has seen a rise in the mean survival age of the mongol.
On the smallest time scale are events at the dynamic intracellular level. Interest here centres on the chromosome constitution. In man each cell contains 46 chromosomes: 22 pairs of autosomes and a pair of sex-chromosomes. In 1959 Lejeune and his co-workers discovered that the mongol possesses an extra autosome - a state of aneuploidy (i.e. an abnormal number of chromosomes). Basically two mechanisms underlie the chromosomal aberrations in mongolism: non-disjunction and translocation. Non-disjunction is the common type. During meiosis there is failure of separation of two homologous chromosomes. Thus one daughter cell will come to contain both components of an autosome pair and the other cell neither. The former, after fertilisation will be trisomic (i.e. it will have three instead of two of a certain chromosome, in this case number 21 on the Denver classification), and will have a diploid number of 47. This situation is seen typically with older mothers and may be related to mechanical factors operating in an old ovary with "old" ova. Less commonly translocation occurs. This involves the breakage of two non-homologous chromosomes and an exchange of fragments between them. The greater part of chromosome 21 becomes attached to one or other fragment leading to a normal diploid number of 46 , but in fact there exists a virtual trisomy 21 . In addition translocation allows of the formation of a carrier state and the defect may therefore be perpetuated through several generations. In essence then, whatever the mechanism, an additional chromosome is overtly or occultly present. A great many genes - each controlling specific metabolic processes - lie $a^{l}$ ong its length. However, the relationship of the cytology to either the biochemistry or to the pathology remains obscure. It is important to realise that the mongol is abnormal from the moment of conception. A degree of developmental irreversibility is attendant at birth and therapy must therefore be more or less ineffective. There is no rationale for the use of thyroid extract, alpha glutavite, siccacell therapy (injection of dried foetal brain cells) or large doses of vitamin $\mathrm{E}$.

\section{(2) Phenylketonuria.}

A somewhat brighter vista is revealed when we look to the inborn error of metabolism, phenylketonuria. This is the paradigm of a genetically determined en- 
zyme-block. It is transmitted as a single autosomal recessive, the homozygous state being necessary for phenotypic expression. The enzyme, phenylalanine hydroxylase, is at fault and there follows failure of oxidation of the essential amino-acid, phenylalanine, to tyrosine. Various intermediate products accumulate proximal to the block and act deleteriously on the nervous system causing profound mental subnormality. Treatment takes the form of a phenylalanine-low diet, and if commenced immediately after birth, offers a reasonable chance of preventing the mental disturbance. Although the heterozygotes are mentally and physically quite normal, they can be detected by means of blood tests (the phenylalanine-load test) and this fact can be utilised in eugenic counseling. Finally, very simple tests are available for diagnosis and have been employed routinely in many maternity centres overseas. This logical application in preventive medicine could be profitably employed in this country.

\section{(B) THE PSYCHOSES.}

Whereas the mental defective lies outside our conceptional world and symbolises all the horror of mute animalism in man, the psychotic may be regarded as a rather interesting eccentric with whom one can still maintain a somewhat narrow contact and communication.

Professor L. A. Hurst stands uniquely and eloquently in relation to psychiatry in South Africa as the protagonist of the hereditary discipline in this field. His researches, disciples and numerous publications on the subject testify cogently to his dynamic influence in a school formerly dominated solely by the environmentalists. He has moreover succeeded in impregnating a matrix of genetic precepts not only into the crude clay of his own speciality, but into the ground-substance of related nedical divisions.

The endogenous psychoses have been shown by the work of F. J. Kallmann in America and Eliot Slater in Britain, to be determined on an autosomal hereditary basis. The genetic mechanism is single recessive in Schizophrenia and irregular dominant in Manic Depressive psychosis. One has illustrated in the case of phenylketonuria how a mutant gene, via the enzyme-block hypothesis, creates a disturbance of cellular chemistry ultimately manifesting in grave mental disintegration. The same basic process is believed to underlie the endogenous psychoses, but it is far more subtle, as yet elusive and cannot be so elegantly demonstrated. It is central to the understanding of the etiogenesis of these psychoses to appreciate the remarkable shift in emphasis implicit in the foregoing statements. For, whereas such mental diseases have been attributed to traumatic psychological experiences, which cause a disturbed and maladjusted psyche, it is now postulated that there is a primary genetic error underlying and indeed creating a disruption at the intracellular level: an imbalance in internal neuronal metabolic milieu. Without elaborating on the detailed biochemistry and in broad terms, mental mechanisms depend upon the interaction of four (or more) endogenous neurohormones, adrenalin, nor-adrenalin, acetylcholine and serotonin. A delicate state of homeostasis between these substances is a pre-requisite for mental normality - imbalance is believed to underlie the genesis of the psychoses considered here. Interestingly enough, many of the drugs used as therapeutic agents have been found to act upon and interfere with the biochemical patterns of the aforementioned neurohormones and have thus furnished further evidence for the indictment of these latter substances in the etiology of the psychoses. Professor Hurst is a strong advocate for the employment of such therapeutic agents as the monoamine oxidase inhibitors (e.g. iproniazid) and the chemically unrelated substance, imipramine in the pin-pointing of the peccant chemical sequences. While much remains to be propounded and still more remains to be clarified, it is apparent that the kaleidoscopic conundrum of the endogenous psychoses has assumed a new colour and format in terms of basic genetic concepts and the elaboration of the latter in the direction of enzyme chemistry, neurochemistry and neuropsychopharmacology.

While these "reflections" have been rather terse and incomplete, they do highlight the emergent fact of an operative genetic component in many forms of mental disorder. Armed with this evidence our knowledge can be translated into practical application in the form of eugenic counseling. A clinic for the provision of this service to the community has been inaugurated at the Johannesburg General Hospital under the aegis of 
Professor Hurst. Genetic advice is furnished in a wide variety of circumstances, not least of all in cases of mental disorder. Present policy is in line with similar clinics in Europe and America: the odds are stated, the genetics of a particular disease is explained and no attempt is made to influence parents as to whether or not they should have children. However, the role of the counselor is not entirely passive as one emphasised at the recent Pretoria Congress on Genetics:

"With regard to the counselor, these very developments in cytologic and biochemical genetics have altered the milieu in which he acts, in as much as his prognostications change in emphasis from passive empiricism to definitive understanding in terms of enzyme-blocks, protein derangements or cytopathogenetics. In addition to mere advice, he is able to thrust back further the barriers of uncertainty and to detect heterozygotes and late onset cases ... Thus far from being an inactive advisor, the counselor, as I see it, converts to the status of active moderator."

In conclusion, it is almost tautological to stress that mental disorder constitues a formidable challenge to the medical world and to society in general. Psychiatry has lagged a little behind the rapid progress made in general medicine - having been snared in a network of classifications and bedevilled with nebulous concepts of " psyche-pathology". It is therefore all the more gratifying to see it caught up now on the giant tidal wave of human genetics - physiologic genetics - and elevated from the esoteric depths of conceptual thinking to the crest of eclectic, concrete formulation and application.

\section{SUMMARY.}

There appears to be a lack of appreciation of the problem of mental disorder on the part of both the medical profession and the lay. man. The current interest in medical genetics has seemed to many to be a somewhat narrow speciality. However, mental disorder and genetic research have in fact been mutually fructifying. Only recently has the hereditary component in mental illness been accorded concrete status in the face of the former prevailing environmentalist doctrine.

Consideration is given to examples within the broader classifications of, (A) Mental Deficiency and (B) The Psychoses.
(A) Simple oligophrenia is briefly alluded to against the polygenic background of intelligence. The discoveries in the cytogenetics of mongolian idiocy are discussed and it is noted that though the key to etiogenesis is now known, the door to the related biochemistry and pathology remains closed. Phenylketonuria is presented as the perfect example of an inborn error of metabolism. Heterozygotes for the condition can be detected by means of blood tests and this constitutes a step forward in terms of eugenic counseling. Treatment with a low phenylalanine diet at birth offers chances of a happy outcome. In view of the success of therapy, and ease of diagnosis, a plea is made for the routine testing of all neo-nates (as practised overseas).

(B) Of the psychoses, manic depressive psychosis and schizophrenia are shown to be genetically determined. Furthermore, the role of the neurohormones, acetylcholine, nor-adrenalin, adrenalin and serotonin in brain physiology is mentioned. Disturbance at the genetic level leads to disturbance in the chemical homeostasis of the aforementioned substances, manifesting ultimately in mental aberration. Many of the drugs used in the treatment of these endogenous pyschoses have furnished further indictment of the part played by the neurohormones in the genesis of mental illness. With entry into the realm of genes, molecules and atoms, our understanding of the psychoses is placed on a fundamental and firm footing.

A Genetic Counseling Unit has been established at the Johannesburg General Hospital under the aegis of Professor L. A. Hurst. Various problems of a medico-genetic nature are dealt with, not least of all, those in the field of mental disorder. It is a happy augury that psychiatry, which has somewhat lagged behind the rapid progress made in general medicine, has attained a clear scientific approach with the incorporation of the basic science of genetics into its discipline.

\section{OPSOMMING.}

Dit lyk asof beide die mediese professie en die leek nie die erns van geestesgebreke insien nie. Die huidige belangstelling in mediese genetika word deur meer as een as 'n baie beperkte rigting van spesialisasie beskou. Geestegebreke en genetiese navorsing het egter, gesamentlik baie vrugte af- 
gewerp. Dit was maar onlangs wat die rol wat oorerwing speel in geestesgebreke sy ware status bereik het, in vergelyking met omgewingsleer.

Spesiale aandag word geskenk aan voorbeelde binne die wyer klasifikasie van, (A) Swaksinnigheid (B) Sielsiekte.

(A) Daar word kortliks verwys na eenvoudige oligofrenie, gesien teen die poligeniese agtergrond van intelligensie. Uit die bespreking van die ontdekkings in die sitogenetika van mongoolse idiootheid is bemerk dat die oorerflikheids oorsake nou bekend is, maar die verwante biochemie en patologie is nog onbekend. Fenielketonurie word voorgehou as die perfekte voorbeeld van 'n aangebore defek van metabolisme. Heterosigote vir die toestand kan opgespoor word deur middel van bloedtoetse en dit is reeds vordering in eugeniese raadgewing. Behandeling met 'n lae fenielalanien dieët met geboorte dui op 'n goeie prognose. $\mathrm{Na}$ aanluiding van die sukses. van terapie en die vergemakliking van diagnose, word 'n beroep gedoen vir die roetine toetsing van alle pasgebore babas (soos oorsee gedoen word).

(B) Van die sielsiektes word die maniesdepressiewe psigose en die gesplete persoonlikheid geneties bepaal. Verder word die rol van neurohormone, asetielkolien, nor-adrenalien, adrenalien en serotonien in brein-fisiologie genoem. Steuring op die genetiese vlak lei tot steurings in die chemiese homeostase van die bogenoemde stowwe, wat uiteindelik geopenbaar word in geestesafwykings. Baie van die verdowingsmiddels, wat gebruik word vir die behandeling van hierdie psigoses, het verdere aanduiding verskaf van die rol wat neurohormone, in die veroorsaking van sielsiektes, speel. Met die toetrede tot die gebied van genes, molekules en atome, het ons begrip 'n vaste grondlegging gekry.

'n Genetiese Raadgewingseenheid is in die lewe geroep by die Johannesburg Algemene Hospitaal onder die beskerming van Prof. L. A. Hurst. Verskei probleme, van mediesgenetiese aard, word ondersoek; waaronder ook probleme op die gebied van geestesgebreke. Dit is verblydend dat psigiatrie, wat agtergeraak het by die snelle vooruitgang van algemene medisyne, 'n suiwer wetenskaplike benadering geniet, met die insluiting van die basiese wetenskap van genetika.

\section{REFERENCES.}

1. Opening Vistas in Psychiatry. L.A. Hurst. Witwatersrand University Press, 1959.

2. Applications of Genetics in Psychiatry and Neurology. L. A. Hurst. S.A. Jnl, of Lab. and Clin. Med. 1958. 4/3. p.169.

3. Converging Advances in Psychiatric Genetics and the Pharmacology of Psychotropic Drugs. L. A. Hurst. Medical Proceedings 1961, 7/20. p. 417.

4. The Genetics of Mental Deficiency. I. F. Anderson. The Leech, Oct. 1962.

5. Genetic Prognosis. I. F. Anderson. 2nd. Congress of S.A. Genetics Society, Pretoria. 1st October, 1962 (in the Press).

6. Phenylketonuria in a Mentally Defective Population. I. F Anderson. (in the Press).

7. The Strategy of the Genes. C. H. Waddington. George Allen and Unwin. Ltd., London. 1957. 